to appoint a special officer, and the East India Company's botanist, Dr. William Roxburgh, held the post from 1793 until 1813. Roxburgh published his "Flora Indica", which became the basis of many subsequent Indian botanical works. In spite of a series of well-known superintendents (F. Buchanan (afterwards Hamilton), N. Wallich, W. Griffith, Hugh Falconer, T. Thomson, T. Anderson, C. B. Clarke, G. King), the Garden suffered vicissitudes of progress and serious set-backs. Cyclones practically devastated the grounds on more than one occasion, and once the Herbarium became seriously depleted through supplying other herbaria too lavishly. Recovery began under the administration of Dr. (afterwards Sir) George King, who retired in 1897 ; and still further improvements were made under Sir David Prain, who succeeded King and remained superintendent until 1905. Since that date, the Garden has continued performing important functions under the administration of several successive superintendents. The present superintendent is $\mathbf{M r}$. K. P. Biswas, who, until his recent promotion, was curator of the Garden Herbarium. For several months since relinquishing his curatorship, Mr. Biswas has been working at the Royal Botanic Gardens, Kew. The Garden lies on the right bank of the River Hooghly, at Sibpur, just outside Calcutta; and is now about 270 acres in extent. Apart from work of a 'pure' botanical nature, much work of economic importance - chiefly to India-is being pursued along lines similar to those obtaining at Kew. The authorities are to be congratulated on the Garden attaining its 150th anniversary, and Mr. Biswas on his recent appointment as superintendent.

\section{An Early Text-book of Chemistry}

THE small text-book on chemistry, "Tyrocinium Chymicum", of Jean Beguin, a native of Lorraine, was first published anonymously in 1610 and went through a large number of editions. The first issue was intended for the use of Beguin's own pupils in a school of pharmacy he established in Paris, but it was pirated and re-issued in Cologne in 1611. Beguin then re-issued it in 1612. Prof. T. S. Patterson, in a paper on "Jean Beguin and his Tyrocinium Chymicum", published in Annals of Science (2, 243298 ; 1937), has given a very full account of the various editions of the book and a description of its contents. As he says, "it is certain, on account of the large number of editions issued, that Beguin's little book was found to be of great practical value, and it must have done much in unostentatious fashion to guide real chemistry along a sound experimental path. . . Beguin was much under alchymical influence.. . but his was a commonsense alchymy and he used its philosophy in an entirely reasonable manner. There was little of the fantastic and nothing of the quack or impostor, or even of the willing dupe or self-deceiver, in him." In a preface by Barth in a later edition, it is said : "Beguin, on account of his virtue, opened his school in Paris-that celebrated emporium of all the wits, and compendium of the whole world-and did not burden his pupils and learners (for princes, counts, nobles, councillors and doctors, attracted by its novelty, meanwhile frequented his chemical laboratory) with useless and prolix comments and various descriptions of his remedies, but prepared in their sight candidly and simply, the secret medicaments of Quercetanus and others, of all kinds both solution and coagulation".

\section{Science and Mankind}

THE Manufacturing Chemist of November includes a further symposium of notes from contemporary scientific workers on "Science and Mankind". Contributions in the October number from Mr. H. G. Wells, Sir Richard Gregory, Prof. L. Hogben, Prof. H. Levy and Sir Daniel Hall are followed by others from Prof. J. B. S. Haldane, who stresses the importance of adequate organization to supply the Press with scientific news, and of thinking rationally about economics and politics, and Mr. C. S. Garland, who directs attention to the vital need for an organization which can speak for science as a whole and of the importance of having representatives in Parliament who are really concerned with the welfare of the profession as a whole. Sir Ernest Graham-Little outlines the contribution which medical science can make to improve social conditions. Dr. W. Cullen, while pointing out that the ultimate effects of a scientific or technical discovery are largely unpredictable, stresses the impossibility of stopping scientific and technical progress and, while con. demning the prostitution of science as in warfare, directs attention to the way in which social conditions have been improved by scientific and technical advances. Prof. Alfred Stock expresses the hope that the progress of chemistry and physics has rendered war so terrible that the use of brute force will be renounced by the nations in reality, and that then science will be able to devote itself completely to the welfare, health and enjoyment of existence of mankind.

\section{Research in Canada}

THE nineteenth annual report of the National Research Council of the Dominion of Canada, for the year 1935-36, refers to the valuable work of the Division of Chemistry on the utilization of Alberta's natural gas. Optimum conditions have been determined for the production of ethylene, and a method has also been developed giving three to four gallons of benzene from each thousand cubic feet of Turner Valley stabilizer gas. Reference is also made to the synthesis of a number of plant hormones and to the discovery that alkaloids of the giant larkspur, a plant growing wild in southern Alberta, are powerful insecticides. The Division of Chemistry has also developed an improved method of measuring the hiding power of paints, and the wax mixture previously developed for use in plucking chickens has now come into wide use in preparing poultry for the market. Dry-cleaning research has included the study of noninflammable cleaning solvents, such as trichloroethylene, the manufacture of which is being undertaken in Canada. The Division of Biology and Agriculture has compiled an extensive review of the 
literature on weed killers as a guide to experimental work in this field. The extent of insecticide taint in wheat, the requirements of barley suitable for malting, especially for the British market, cold storage of fowls, fruit and other food products have all received attention, and physical conditions necessary for dechilling boxed poultry have been established which prevent the formation of condensate, a blemish which lowers the market quality.

THe Division of Physics and Engineering has been responsible for a good deal of standardization work in co-operation with the National Bureau of Standards, Washington. A 'reverberation chamber' has been built and used for measurements of the soundabsorbing properties of various kinds, building materials for Government departments and commercial firms. Apparatus completed during the year has enabled the Division to make thermal insulation tests on large samples of insulating materials, partitions and wall sections. An experimental investigation of the heating of railway refrigerator cars in winter has been completed, and in addition to aerial surveys the Division has been concerned with a number of aviation problems, including the development of a new type of aircraft ski. The Division of Research Information is being vigorously developed and the report also refers to conferences on forestry and fish culture and to the work of a number of associate committees, as well as to the assisted researches, for which grants amounting to 158,968 dollars were provided during the year, and to the 685 scholarships awarded to 385 persons, representing total grants of 570,053 dollars.

\section{Cancer Research in Australia}

THE report of the eighth Australian Cancer Conference, which was held in Canberra in April last, shows that it was a meeting well attended by representatives from Australasia. The recommendations of the Conference of the previous year appear to have been largely acceptable to the Commonwealth Government for, on September 24, 1936, a National Health and Medical Research Council was instituted by an Order in Council. The recommendation that the Commonwealth Government should appoint an Australian Cancer Commission did not, however, prove acceptable. Among other resolutions of the present year's Conference may be mentioned a recommendation that the Commonwealth Government should make available the sum of $£ 30,000$ annually for the purpose of establishing a permanent and reliable system of medical research. There is little doubt that a most lively interest is being taken officially by Australia in the subject of cancer among its population. This is reflected not only in public action but also in the publications which appear from time to time dealing with various aspects of this subject. "Physical Aspects of Radium and Radon Therapy" is a booklet prepared by Dr. C. E. Eddy, physicist-in-charge of the Commonwealth $\mathrm{X}$-ray and Radium Laboratory of the University of Melbourne, and Mr. T. H. Oddie, more especially for the use of radiotherapists and officers of local physical services. The booklet of sixty pages gives an extremely good account of the general physics of the substances and radiations used in radiotherapy together with an account of precautions necessary in using them. The relative advantages and disadvantages of radium and radon are also dealt with in a thoroughly explicit manner.

\section{Edible Birds Nests in the Philippines}

The edible nests of swiftlets, valued as a delicacy and as food for convalescents by the people of China, are built in limestone caves along the seashore in many parts of the Philippines. The export of the nests is in the hands of local Chinese merchants, and although accurate statistics are difficult to obtain it has been stated that the Netherlands Indies in 1927 exported 109,310 kilograms of nests valued at 822,913 guilders. In only one of the Philippine Islands, Bacuit, has an attempt been made to derive municipal revenue from the trade, when in 1927 the traditional ownership of the birds nest caves, which had existed for generations, was supplanted by municipal ownership and the annual leasing of the caves to the highest bidder. As a reply to this move, the Chinese dealers formed a ring so that the bidding, which reached 1,700 pesos in 1927 , had fallen in 1936 to 500 pesos, and in a footnote to a recent paper on the subject, Canuto G. Manuel states that as no bid at all was offered in 1937 , the caves have relapsed to the system of traditional ownership (Philippine J. Sci., 62, 379, March 1937). From Bacuit, approximately 500 kilograms or about 100,000 nests are exported annually, but poaching of nests is common, and attempts to limit the collecting with the view of conserving the stock have met with little success. Nest collecting, however, is a dangerous occupation, and the fact that some inaccessible caves are tenanted by the birds, which belong to the racial form, Collocalia francica germani, provides for the survival of the swiftlet.

\section{Literature of Food Investigation}

IN its report for 1936, the Food Investigation Board stated that a committee had been appointed to review both the scope and the form of its publication, "The Index to the Literature of Food Investigation". The first number of this journal appeared in 1929 and at present it covers about a hundred scientific and technical periodicals, each number containing upwards of 2,000 references, in the form of elaborated titles that indicate the scope of the papers indexed, but omit all experimental data. The original intention was that the "Index" should deal solely with the transport and storage of foodstuffs; it now tends to cover, however, the wider diverse field that lies between agriculture, or production, and nutrition, or the use of food for the maintenance of health. The first number of volume 7, which covers the literature published in 1934, has been issued ("Index to the 